\title{
Novel biomarkers predict liver fibrosis in hepatitis C patients: alpha 2 macroglobulin, vitamin $D$ binding protein and apolipoprotein Al
}

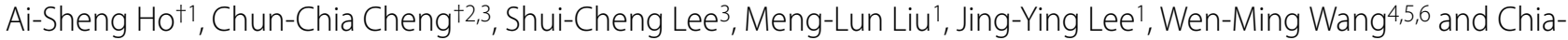 \\ Chi Wang*7
}

\begin{abstract}
Background: The gold standard of assessing liver fibrosis is liver biopsy, which is invasive and not without risk. Therefore, searching for noninvasive serologic biomarkers for liver fibrosis is an importantly clinical issue.

Methods: $A$ total of 16 healthy volunteers and 45 patients with chronic hepatitis $C$ virus (HCV) were enrolled (FO: $n=$ $16, F 1: n=7, F 2: n=17, F 3: n=8$ and F4: $n=13$, according to the METAVIR classification). Three serum samples of each fibrotic stage were analyzed by two-dimension difference gel electrophoresis (2D-DIGE). The differential proteins were identified by the cooperation of MALDI-TOF/TOF and MASCOT; then western blotting and Bio-Plex Suspension Array were used to quantify the protein levels.
\end{abstract}

Results: Three prominent candidate biomarkers were identified: alpha 2 macroglobulin (A2M) is up regulated; vitamin D binding protein (VDBP) and apolipoprotein $\mathrm{Al}(\mathrm{ApoAl})$ are down regulated. The serum concentration of A2M was significantly different among normal, mild (F1/F2) and advanced fibrosis (F3/F4) $(p<0.01)$. The protein levels of VDBP and ApoAl were significantly higher in normal/mild fibrosis, when compared to those in advanced fibrosis (both $p<$ $0.01)$.

Conclusions: This study not only reveals three putative biomarkers of liver fibrosis (A2M, VDBP and ApoAl) but also proves the differential expressions of those markers in different stages of fibrosis. We expect that combination of these novel biomarkers could be applied clinically to predict the stage of liver fibrosis without the need of liver biopsy.

\section{Introduction}

In hepatitis $\mathrm{C}$ virus (HCV)-infected patients, liver fibrosis is a noticeable disease and could progress to liver cirrhosis or hepatocellular carcinoma gradually. Although the pathogenesis of HCV-infected fibrosis is poorly understood, liver fibrosis may be a response of repair when liver is injured or inflamed [1]. In addition, the detection of early stage of liver fibrosis is very important before the irreversible damage occurs. Liver biopsy followed by histological examination is still the gold standard for the assessment of liver fibrosis [2]. However, it has several limits and disadvantages such as invasive character and

\footnotetext{
* Correspondence: uld888@yahoo.com.tw

7 Division of Gastroenterology, Buddhist Tzu Chi General Hospital, Taipei branch, Taiwan

+ Contributed equally

Full list of author information is available at the end of the article
}

sampling error [3-5]. Therefore, it is necessary to have a reliable and noninvasive assessment for liver fibrosis.

Two-dimension difference gel electrophoresis (2DDIGE), first proposed by Unlu et al [6], allow different samples to be labeled with cy3 or cy 5 flour in one gel. It used cy2-labeled internal standard to tell the differences and found out the reliable biomarkers among different gels. Furthermore, multi-analyte profiling (xMAP) technique was used to quantify the concentration of putative biomarkers. By using these methods, we could not only identify but also quantify the candidate biomarkers, which could be a serologic predictor for the severity of liver fibrosis. In this study, we enrolled patients of chronic $\mathrm{HCV}$ infection and healthy controls, and used proteomic technique to analyze their sera. The aim is to search for noninvasive serological biomarkers of liver fibrosis,

(c) 2010 Ho et al; licensee BioMed Central Ltd. This is an Open Access article distributed under the terms of the Creative Commons Attri:H Wed Central bution License (http://creativecommons.org/licenses/by/2.0), which permits unrestricted use, distribution, and reproduction in any medium, provided the original work is properly cited. 
which could predict the stage of fibrosis without the need of liver biopsy.

\section{Materials and methods Serum samples}

Totally 61 serum samples from 45 patients of chronic $\mathrm{HCV}$ infection and 16 healthy volunteers were obtained from Cheng Hsin General Hospital in Taiwan (approval No. 97016). The assessment of liver fibrosis was based on liver biopsy and subsequent histological examination. The stage was determined according to METAVIR classification [7]. The stages of liver fibrosis were distributed as following in the chronic hepatitis $C$ patients: $F 1, n=7, F 2$, $\mathrm{n}=17, \mathrm{~F} 3, \mathrm{n}=8$ and $\mathrm{F} 4, \mathrm{n}=13$. The serum samples of healthy control (F0 stage, $\mathrm{n}=16$ ) were obtained from healthy volunteers who had no evidence of known hepatitis. Liver biopsy was not performed in these subjects due to ethical issues.

\section{Two dimension-difference gel electrophoresis}

The serum samples were diluted 1:5 with lysis buffer (50 $\mathrm{mM}$ Tris- $\mathrm{HCl}, 8 \mathrm{M}$ urea, $4 \%(\mathrm{w} / \mathrm{v})$ 3-[(3-Cholamidopropyl) dimethylammonio]-1-propanesulfonate, and $\mathrm{pH}$ 8.5). The protein concentration was measured $\left(\mathrm{DC}^{\mathrm{m}}\right.$ Protein Assay Kit, Bio-Rad) and individual $50 \mu \mathrm{g}$ of protein sample was allowed to label with 400 pmol of cy3 or cy5. In addition, pooled internal standard $(400 \mu \mathrm{g})$ was allowed to label with $3200 \mathrm{pmol}$ of cy2. Subsequently the solution was added $1 \mu \mathrm{L}$ of $10 \mathrm{mM}$ lysine to stop the reaction. The serum samples of labeled-cydyes and its arrangement are presented in Table 1. Each mixture was added twofold volume of sample buffer ( $8 \mathrm{M}$ urea, $20 \mathrm{mM}$ dithiothreitol, $4 \%(w / v) 3-[(3-C h o l a m i d o p r o p y l)$ dimethylammonio]-1propanesulfonate, $0.5 \%(\mathrm{v} / \mathrm{v})$ IPG buffer and few bromophenol blue) and performed with $18 \mathrm{~cm}, \mathrm{pH}$ 4-7 IPG strips for the isoelectric focusing (IEF) at $20^{\circ} \mathrm{C}(30000 \mathrm{Vh})$ (IPGphor system, GE Healthcare). After equilibration, the strips were overlaid on individual $12.5 \%$ polyacrylamide gels and added $0.5 \%$ agarose to immobile the strips. After electrophoresis, the cy2, cy3, and cy5-labeled images were acquired (Typhoon TRIO Variable Mode Imager, GE Healthcare) using 488, 532, and $633 \mathrm{~nm}$ lasers with an emission filter of 520,532, and $670 \mathrm{~nm}$ respectively. All gels were analyzed by using DeCyder 6.5 software (GE Healthcare) to select and match all protein spots. The estimated number of spots was set at 10000 . Spot maps of the filtered gels were saved and imported to Biological Variation Analysis program for inter-gel matching and statistical analyses. The interesting protein spots were selected according to one-way ANOVA with a significant value of 0.05 or less.

\section{In-gel tryptic digestion}

The gels were stained with Sybro Ruby (sigma) for at least four hours and then destained with 10\% methanol/7\% acetic acid for exactly $30 \mathrm{~min}$. The interesting proteins in the gels were picked up manually on UV transilluminator (Spectroline). Those gel particles were washed with 10\% methanol/7\% acetic acid overnight to remove Sybro Ruby chemicals thoroughly; $100 \mu \mathrm{L}$ of $25 \mathrm{mM}$ ammonium bicarbonate in $50 \%$ acetonitrile for $15 \mathrm{~min} ; 200 \mu \mathrm{L}$ of 25 $\mathrm{mM}$ ammonium bicarbonate in deionized water for 15 min twice. The saturated gel particles were added enough acetonitrile to shrink for $5 \mathrm{~min}$. After drying down, the gel particles were added $3 \mu \mathrm{L}$ of $20 \mathrm{ng} / \mu \mathrm{L}$ trypsin in 25 $\mathrm{mM}$ ammonium bicarbonate at $4^{\circ} \mathrm{C}$ for 1 hour and subsequently added $3 \mu \mathrm{L}$ of $25 \mathrm{mM}$ ammonium bicarbonate to keep the gels wet at $56^{\circ} \mathrm{C}$ for 1 hour. After In-gel digestion the solution were added $2 \mu \mathrm{L}$ of $100 \%$ acetonitrile with $1 \%$ trifluoracetic acid and sonicated for $10 \mathrm{~min}$ to release peptides from gel particles.

\section{Mass spectrometric analysis for protein identification}

Each trypsin-digested solution was mixed 1:1 with 10 $\mathrm{mg} / \mathrm{mL} \alpha$-cyano-4-hydroxycinnamic acid in $50 \%$ acetonitrile $/ 0.1 \%$ trifluoracetic acid and spotted on AnchorChip MALDI target (Bruker Daltonics GmbH, Bremen, Germany). Peptides were analyzed with MALDI-TOF/TOF UltraflexIII (Bruker Daltonics) by peptide mass fingerprinting after calibration in positive

Table 1: Arrangement for protein samples labeled with three CyDye flours

\begin{tabular}{llll}
\hline Gel & Cy2 & Cy3 \\
\hline 1 & Pool of samples & F0 (1) \\
2 & Pool of samples & F3 (1) \\
3 & Pool of samples & F0 (3) & F2 (2) \\
4 & Pool of samples & F1 (2) & F4 (2) \\
5 & Pool of samples & F3 (1) & F3 (3) \\
7 & Pool of samples & F0 (1) \\
\hline
\end{tabular}


reflection mode under $20 \mathrm{KV}$ and calculated the molecular weight with FlexAnalysis ${ }^{\mathrm{mm}} 3.0$ software (Bruker Daltonics). MASCOT 2.2 (Matrix Science) was used to match the peptides with NCBI or Swiss-Prot database for protein identification. The calculation was restricted to human taxonomy, allowing carbamidomethyl cysteine as a fixed modification and oxidized methionine as a variable modification. The probability was based on Mowse score calculated from $-10 \times \log (\mathrm{P})$, where $\mathrm{P}$ was the probability that the observed match was a random event. Protein scores greater than 56 were significant $(p<0.05)$. Moreover, one of the major peptide peaks appeared on the spectrum was used to confirm the searching result by peptide fragment fingerprinting method.

\section{Western blotting}

Each serum sample was diluted 1:10 with sodium dodecyl sulfate buffer (50 mM Tris- Cl, $8 \mathrm{M}$ urea, 30\% glycerol, 2\% sodium dodecyl sulfate, $20 \mathrm{mM}$ dithiothreitol and $0.1 \%$ bromophenol blue). The sample solutions were heated at $100^{\circ} \mathrm{C}$ for $5 \mathrm{~min}$; and then $2 \mu \mathrm{L}$ of samples (approximately 20-30 $\mu \mathrm{g}$ ) were loaded to $4-12 \%$ sodium dodecyl sulfatepolyacrylamide gel electrophoresis (SDS-PAGE, Invitrogen). The iblot (Invitrogen) was used for transforming the proteins to polyvinylidene fluoride (PVDF). After using $0.5 \%$ milk to blot the PVDF for $30 \mathrm{~min}$, the A2M, ApoAI and VDBP were detected by rabbit anti-A2M antibody (AbD serotec), chicken anti-ApoAI antibody (CHEMI$\mathrm{CON}$ ) and rabbit anti-VDBP antibody (AbD serotec) for two hour at room temperature. After washing three times in PBS buffer (10 mM sodium phosphate, pH7.4 and 0.9\% sodium chloride), the second antibody conjugated with horseradish peroxidase was added to incubate for one hour. The ECL detection system (Millipore) was used and the images were acquired by Imaging System (Gel Doc XR System, Bio-Rad) depending on the moderate exploring time.

\section{Bio-plex suspension array system}

Bio-Plex 200 Suspension Array System (Bio-Rad) was based on flexible multi-analyte profiling (xMAP) technique developed by Luminex Corporation using the principle of sandwich immunoassay. Individual serum sample was diluted 100 thousands fold with Bio-Plex human serum diluent. For A2M measurement, Bio-Plex Pro Human Acute Phase 4-Plex Panel (cat. 171-A4009M, BioRad) was performed. For ApoAI and VDBP measurement, there are many processes need to complete, including antibody labeled with microsphere and biotin individually. These experiments were completed by following the manual of Amine Coupling Kit (Bio-Rad) and Lynx Rapid Biotin Antibody Conjugation Kit (AbD Serotec) respectively. After pre-wet of 96-well plate, each 50 $\mu \mathrm{L}$ of diluted sample was incubated with $1.25 \times 10^{6}$ microspheres, which labeled with primary antibody, at $300 \mathrm{rpm}$ for exactly 1 hour. Subsequently each $50 \mu \mathrm{L}$ of biotin-conjugated secondary antibody $(2 \mu \mathrm{g} / \mathrm{mL})$ was added to incubate at $300 \mathrm{rpm}$ for $30 \mathrm{~min}$. Finally $50 \mu \mathrm{L}$ of streptavidin-Phycoerythrin was added to each well and mixed at $300 \mathrm{rpm}$ for $10 \mathrm{~min}$. After drying up and washing, $125 \mu \mathrm{L}$ of assay buffer was allowed to suspend each well of microspheres. The protein concentration was measured by Bio-Plex 200 Suspension Array System. SPSS software (Ver.14.0; SPSS Inc.) was used to calculate the $p$ value and to present the curve of expressional trend with Box-and-Whisker Plot.

\section{Results}

The serum samples labeled with cy2, cy3 or cy5 individually are presented in Table 1. From F0 to F4 fibrotic stages, we selected three samples of each stage to do 2DDIGE experiments. For this purpose, 15 samples needed to separate into eight gels, in which F0-1 was used in gel 1 and gel 8 for fitting the arranging design. This design would not influence the data calculation. In this study we did not use albumin/IgG removal kit to remove high abundant albumin and IgG because we wanted to simplify the experimental process. Moreover removing albumin protein would remove albumin-binding proteins in the same time and influence the reproducibility.

After the protein matching and statistics calculation with DeCyder 6.5 software, there were three putative proteins selected $(p \leq 0.05)$. These protein locations in 2DPAGE gel are shown in Fig. 1. The three putative proteins

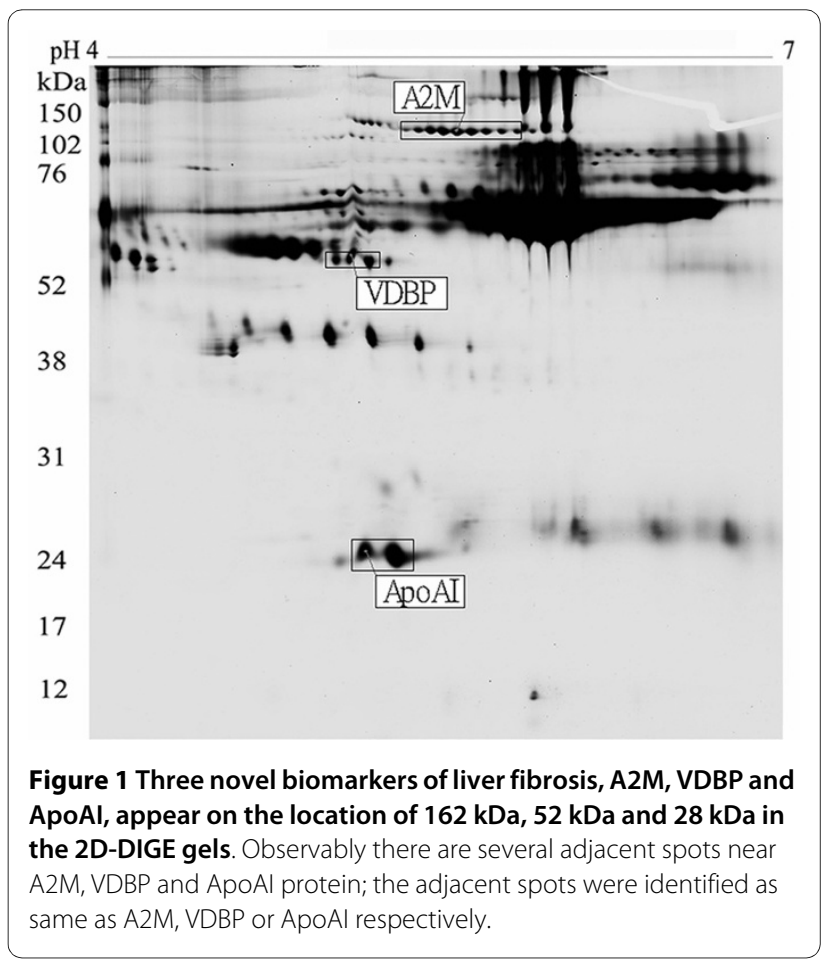


were found out that they all appeared in eight gels (Fig. 2A, Fig. 2B and Fig. 2C). The three proteins were excised from gels, digested with trypsin, and identified by the cooperation of MALDI-TOF/TOF with MASCOT software (link to NCBI database, http:// www.ncbi.nlm.nih.gov/). Alpha 2 macroglobulin (A2M) is up regulated whereas vitamin $\mathrm{D}$ binding protein (VDBP) and apolipoprotein AI (ApoAI) are down regulated in hepatic fibrosis serum (Fig. 2D, Fig. 2E and Fig. 2F; Table 2). Meanwhile, we noticed that A2M protein had a series of adjacent spots appeared in 2D-PAGE; besides, VDBP and ApoAI had two and one adjacent spots respectively (Fig. 1). Those different spots were identified as the same results as A2M, VDBP or ApoAI respectively.

Although 2D-DIGE analyses already demonstrated that the protein levels and expressional trends for each candidate biomarkers were apparently distinct in fibrotic stages, using antibody to verify the result was important. We selected two samples of each fibrotic stage to analyze the protein expressions by using western blotting for verifying the protein identification. A2M was detected having higher protein expression in F1-F4 stage than in F0 stage (Fig. 3A). Moreover, VDBP and ApoAI were down regulated (Fig. 3A). Particularly the protein expression of VDBP from mild fibrosis (F0/F1) to advanced fibrosis (F2-F4) was decreased (Fig. 3A and Fig. 3C). The protein expression of ApoAI was changeable only in F3/F4 compared with that in F0-F2 stage (Fig. 3A and Fig. 3D).

We used Bio-Plex Suspension Array System to measure the absolute protein concentration of A2M, VDBP and ApoAI according to protein standard curve. We found that the serum concentration of A2M from F0 to F4 was increased significantly (F0: $4.3 \pm 2.8, \mathrm{~F} 1 / \mathrm{F} 2: 7.2 \pm 4.3$, F3/ F4: $13.0 \pm 6.8 \mathrm{mg} / \mathrm{mL}, p<0.01$ ) (Fig. 3B). The correlation coefficient of A2M was 0.98 . The result suggests that A2M protein could distinguish the stages among normal (F0), mild (F1/F2) and advanced fibrosis (F3/F4). The serum concentration of VDBP was decreased from F0/F1 to F2-F4 stage (F0/F1: $1.2 \pm 0.3 \mathrm{mg} / \mathrm{mL}, \mathrm{F} 2-\mathrm{F} 4: 0.6 \pm 0.2$ $\mathrm{mg} / \mathrm{mL}, p<0.01$ ) (Fig. 3C). The result indicates that VDBP protein could differentiate F0/F1 from F2-F4 stage. The protein concentration of ApoAI was decreased in F3/

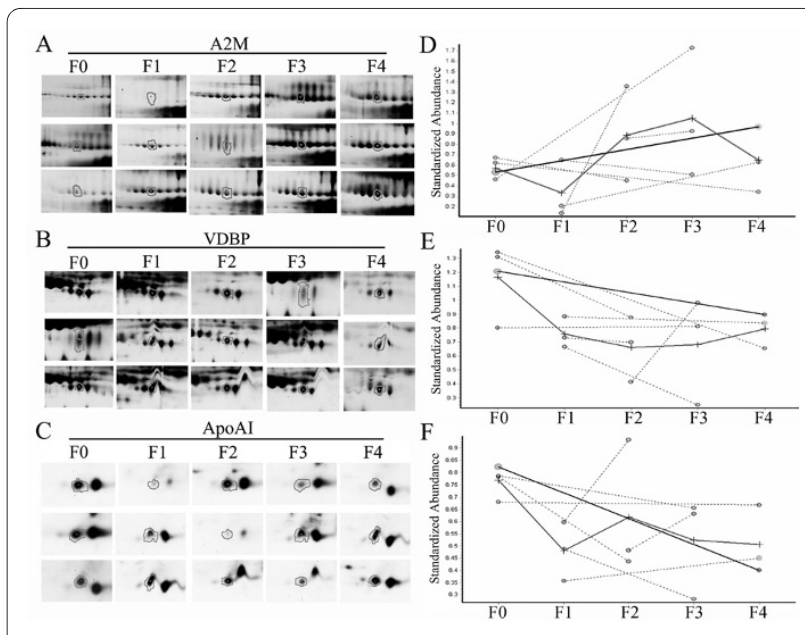

Figure 2 The protein expressions of A2M (A), VDBP (B) and ApoAI (C) are presented in eight gels. The expressional trends of $A 2 M(D)$, VDBP (E) and ApoAI (F) were calculated with DeCyder 6.5 software. $\mathrm{A} 2 \mathrm{M}$ is an up-regulated protein; $\mathrm{VDBP}$ and $\mathrm{ApoAl}$ are down-regulated proteins with hepatic fibrosis development.

F4 stage (F0-F2: $2.0 \pm 0.7 \mathrm{mg} / \mathrm{mL}, \mathrm{F} 3 / \mathrm{F} 4: 1.1 \pm 0.5 \mathrm{mg} /$ $\mathrm{mL}, p<0.01$ ) (Fig. 3D). This result implies that ApoAI could be a biomarker to differentiate normal/mild (F0F2) from advanced fibrosis (F3/F4).

\section{Discussion}

Searching for novel serological biomarkers of HCVinfected fibrosis is to avoid the use of invasive liver biopsy. Developing an efficient and noninvasive method for liver fibrosis is important for prognosis and treatment plan in patients with chronic hepatitis $\mathrm{C}$ virus. A noninvasive diagnosis of liver fibrosis could also enhance the development of antifibrotic therapies. There are several non-invasive methods to assess liver fibrosis in patients with chronic hepatitis C, including FibroScan (FS) [8,9], Fibrotest (FT) [10]. However, FS could not assess liver fibrosis properly when patients were overweight or morbid obese; besides, stiffness measurement is hard to acquire in ascitic patients [8]. Ziol M et al. [11] indicated that FS appeared as a reliable tool to detect significant fibrosis or cirrhosis rather than early liver fibrosis. Cast-

Table 2: Protein spots identified by MALDI/TOF-TOF-MS

\begin{tabular}{cccc}
\hline Protein & GenBank & coverage ratio & regulation \\
\hline A2M & gi: 224053 & $29 \%$ & 0.015 \\
VDBP & gi: 18655424 & $38 \%$ & 0.020 \\
ApoAl & gi:90109664 & $49 \%$ & 0.027 \\
\hline
\end{tabular}

${ }^{\S} \mathrm{A} 2 \mathrm{M}$, alpha 2 macroglobulin; VDBP, vitamin D binding protein; ApoAl, apolipoprotien Al. ${ }^{9}$ The $p$ value was calculated by one way ANOVA with DeCyder 6.5 software. \#, present in normal and each fibrotic stage but the protein expression in fibrotic stages (F1-F4) is higher than that in normal control (F0); $\exists$, present in normal and each fibrotic stage but the protein expression in moderate/advanced fibrotic stages (F3/F4) is lower than that in normal control/mild fibrotic stage (F0/F1). 


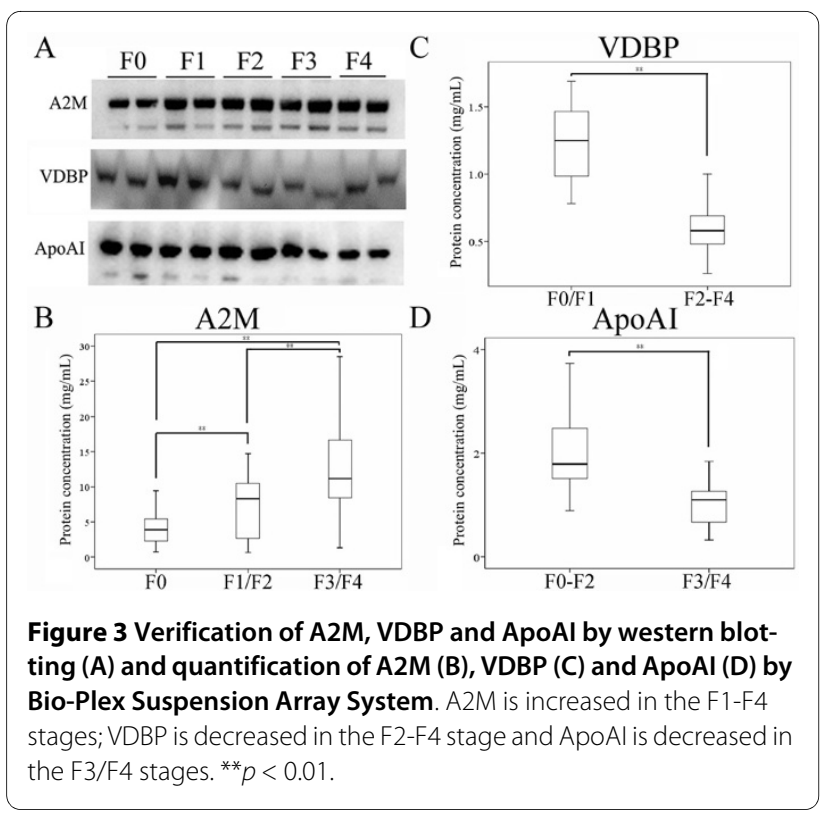

era $L$ et al. [12] suggested that the combined use of FS and FT to assess liver fibrosis could avoid liver biopsy in most patients with chronic hepatitis C. In our study, although two of the three identified biomarkers, A2M and ApoAI, are the same as that in FT, ApoAI is decreased significantly only in advanced fibrosis (F3/F4). This result suggests ApoAI could only be an indictor for advanced fibrosis or cirrhosis. In addition, this is the first report that VDBP could be a biomarker of liver fibrosis in patients with chronic hepatitis $C$.

A2M is a well-known biomarker of hepatic fibrosis [13] and a significant component of measuring liver fibrosis in FibroTest, FIBROSpect II, Fibrometer or Hepascore $[10,14-16]$. A2M is able to inactivate an enormous variety of proteinases and inhibit fibrinolysis by reducing plasmin and kallikrein. In inflammatory or injured liver, the increase of A2M inhibit catabolism of matrix proteins and thus cause liver fibrosis [17-20]. Gangadharan B et al. indicated that thioester cleavage of A2M may increase gradually with the development of fibrosis [21]. In our study, we consistently confirmed that serum concentration of A2M may be an indicator to predict liver fibrosis. However, serum A2M level is increased in patients with depression or nephrotic syndrome [22,23]. Therefore, while using A2M as liver fibrosis biomarker, other biomarkers are needed to decrease the interference of other diseases such as nephrotic syndrome or depression.

VDBP is also known as Gc-globulin (group-specific component globulin) which binds and transports vitamin D metabolites [24,25]. The significant function of VDBP is involved in actin scavenger system, thus to protect the organism from the toxic effect of intravascular actin polymerization [26]. Moreover, VDBP can also be converted into a macrophage-activator factor, and actin-free
VDBP is associated with organ dysfunction in acute liver failure $[27,28]$. However, this is the first study to validate that the level of VDBP is negatively associated with the development of liver fibrosis. ApoAI, applied also in FibroTest and Fibrometer test [29,30], was a putative biomarker of $\mathrm{HCV}$-infected fibrosis which was also verified to be a protein with down regulation in liver hepatic fibrosis in this study. Moreover, we found that the level of ApoAI was changeable between F0-F2 and F3/F4 stage. Our result demonstrates that ApoAI is a candidate biomarker of advanced fibrosis (F3/F4).

2D-DIGE technologies, a useful tool in proteomics analysis recently, were used to search for reliable biomarker of liver fibrosis in our study. Cy2-labeled internal standard can correct the analytical error among gels so that more than two samples can be analyzed. Furthermore, the samples, which were labeled with high sensitive CyDye, could pour together in one gel. Thus, thousands of serum proteins could be easily analyzed and identified as reliable biomarkers [31,32]. In addition, there were several advantages for 2D-DIGE technique such as reducing variation among gels and increasing the reproducibility of proteins [33]. The sensitivity of CyDye flours $(<0.05$ ng) was better than silver staining or coomassine blue staining [34,35]. Therefore 2D-DIGE was more powerful than traditional two-dimension electrophoresis (2DE) in biomarker discovery. However, it still had some limitations in detecting the hydrophobic proteins, proteins bigger than $200 \mathrm{kDa}$, or those smaller than $10 \mathrm{kDa}$. Many proteins of extreme acidity or basicity were also not presented in the gels [36]. Moreover, because CyDye flours needed to conjugate with lysine residue of proteins, the high abundant proteins with few or no lysine residues were difficult to be detected.

The mean in distinct stages was used as cut-off value to define the severity of liver fibrosis (A2M: $<4.3 \mathrm{mg} / \mathrm{mL}$, score $0 ; 4.3-7.2 \mathrm{mg} / \mathrm{ml}$, score $1 ; 7.2-13.0 \mathrm{mg} / \mathrm{ml}$, score 2 ; $>13.0 \mathrm{mg} / \mathrm{ml}$, score 3 ; VDBP: $>1.2 \mathrm{mg} / \mathrm{mL}$, score $0 ; 0.6-1.2$ $\mathrm{mg} / \mathrm{ml}$, score $1 ;<0.6 \mathrm{mg} / \mathrm{ml}$, score 2; ApoAI: $>2.0 \mathrm{mg} / \mathrm{mL}$, score $0 ; 1.1-2.0 \mathrm{mg} / \mathrm{ml}$, score $1 ;<1.1 \mathrm{mg} / \mathrm{ml}$, score 2 , Table $3)$. In this algorithm, the combining score of three biomarkers from 0 to 3 represent normal (F0/F1); score from 4 to 7 represent liver fibrosis (F2-F4). The sensitivity and specificity are $75 \%$ and $79 \%$ respectively. Furthermore, the stages of liver fibrosis from F1 to F4 could be predicted accurately (the median of combining score: $\mathrm{FO}=2$, $\mathrm{F} 1=2.5, \mathrm{~F} 2=4, \mathrm{~F} 3=4.5, \mathrm{~F} 4=6$ ). As we know, the main problem of available serologic tests to predict the stage of liver fibrosis is the tiny difference between F1 and F2; F2 and F3. The addition of these biomarkers especially VDBP and ApoAI in the algorithm could be helpful to separate these two stages of liver fibrosis. Whether combining other known biomarkers of liver fibrosis such as tissue inhibitor of metalloproteinases-1 (TIMP-1), 
Table 3: Cut-off value of A2M, VDBP and ApoAl to predict liver fibrosis $\$$

\begin{tabular}{lllll}
\hline A2M & $<4.3$ & $4.3-7.2$ & $7.2-13.0$ & 3 \\
Score & 0 & 1 & 2 & 3.0 \\
\hline VDBP & $>1.2$ & $0.6-1.2$ & 2 \\
Score & 0 & 1 & $<0.6$ \\
\hline ApoAl & $>2.0$ & $1.1-2.0$ & 2 & 21.1 \\
Score & 0 & 1 & 2 \\
\hline
\end{tabular}

\$The measuring unit is $\mathrm{mg} / \mathrm{mL}$. In this algorithm of three biomarkers, combining score from 0 to 3 present normal (F0/F1); score from 4 to 7 present liver fibrosis (F2-F4). A2M, alpha 2 macroglobulin; VDBP, vitamin D binding protein; ApoAl, apolipoprotien Al.

hyaluronic acid (HA), N-terminal propeptide of type III procollagen (PIIINP) or YKL-40 [30,37,38] may increase the sensitivity and specificity of this algorithm needs further studies to confirm.

In summary, this study not only reveals three putative biomarkers of liver fibrosis (A2M, VDBP and ApoAI) but also proves the differential expressions in different stages of fibrosis. Furthermore, we discovered a novel biomarker, VDBP, which is decreased in liver fibrosis (F2F4). In addition, the algorithm combining three biomarkers could be used clinically to predict the stage of liver fibrosis and to reduce the use of liver biopsy.

\section{Competing interests}

The authors declare that they have no competing interests.

\section{Authors' contributions}

ASH assisted with diagnosis for patients and collection of fibrotic serum samples; CCC assisted with article writing, protein identification from the gel spots and western blotting experiment; MLL and JYL assisted with preparation for the serum samples and judgment for fibrotic stages; $\mathrm{SCL}$ and WMW were projective leaders and assisted with experimental design; CCW assisted with article revising. All authors read and approved the final manuscript.

\section{Acknowledgements}

This project was supported by the grant NSC96-3111-P-042A-004-Y from National Science Council of Republic of China and the founding of Cheng Hsin Rehabilitation Medical Center.

\section{Author Details}

1Division of Gastroenterology, Cheng Hsin General Hospital, Taipei, Taiwan, ${ }^{2}$ Graduate Institute of Medical Sciences, College of Medicine, Taipei Medical University, Taipei, Taiwan, 3Institute of Nuclear Energy Research, Atomic Energy Council, Taoyuan, Taiwan, ${ }^{4}$ Division of Internal Medicine, Kaohsiung Municipal Hsiao-Kang Hospital, Kaohsiung Medical University, Kaohsiung, Taiwan, 5Division of Gastroenterology, Department of Internal Medicine, Kaohsiung Medical University Hospital, Kaohsiung, Taiwan, ${ }^{\circ}$ Department of Medicine, Faculty of Medicine, College of Medicine, Kaohsiung Medical University, Kaohsiung, Taiwan and ${ }^{7}$ Division of Gastroenterology, Buddhist Tzu Chi General Hospital, Taipei branch, Taiwan

Received: 24 August 2009 Accepted: 15 July 2010

Published: 15 July 2010

\section{References}

1. Marcellin P: Hepatitis C: the clinical spectrum of the disease. J Hepatol 1999, 31(Suppl 1):9-16.

2. Afdhal NH, Nunes D: Evaluation of liver fibrosis: a concise review. Am J Gastroenterol 2004, 99:1160-1174.
3. Thampanitchawong P, Piratvisuth T: Liver biopsy:complications and risk factors. World J Gastroenterol 1999, 5:301-304.

4. Regev A, Berho M, Jeffers LJ, Milikowski C, Molina EG, Pyrsopoulos NT, Feng ZZ, Reddy KR, Schiff ER: Sampling error and intraobserver variation in liver biopsy in patients with chronic HCV infection. Am J Gastroenterol 2002, 97:2614-2618.

5. Poynard T, Ratziu V, Bedossa P: Appropriateness of liver biopsy. Can J Gastroenterol 2000, 14:543-548.

6. Unlu M, Morgan ME, Minden JS: Difference gel electrophoresis: a single gel method for detecting changes in protein extracts. Electrophoresis 1997, 18:2071-2077.

7. Bedossa P, Poynard T: An algorithm for the grading of activity in chronic hepatitis C. The METAVIR Cooperative Study Group. Hepatology 1996, 24:289-293.

8. Sandrin L, Fourquet B, Hasquenoph JM, Yon S, Fournier C, Mal F, Christidis C, Ziol M, Poulet B, Kazemi F, Beaugrand M, Palau R: Transient elastography: a new noninvasive method for assessment of hepatic fibrosis. Ultrasound Med Biol 2003, 29:1705-1713.

9. Saito H, Tada S, Nakamoto N, Kitamura K, Horikawa H, Kurita S, Saito Y, I wai $\mathrm{H}$, Ishii H: Efficacy of non-invasive elastometry on staging of hepatic fibrosis. Hepatol Res 2004, 29:97-103.

10. Imbert-Bismut F, Ratziu V, Pieroni L, Charlotte F, Benhamou Y, Poynard T: Biochemical markers of liver fibrosis in patients with hepatitis $C$ virus infection: a prospective study. Lancet 2001, 357:1069-1075.

11. Ziol M, Handra-Luca A, Kettaneh A, Christidis C, Mal F, Kazemi F, de Lédinghen V, Marcellin P, Dhumeaux D, Trinchet JC, Beaugrand M: Noninvasive assessment of liver fibrosis by measurement of stiffness in patients with chronic hepatitis C. Hepatology 2005, 41:48-54.

12. Castéra L, Vergniol J, Foucher J, Le Bail B, Chanteloup E, Haaser M, Darriet M, Couzigou P, De Lédinghen V: Prospective comparison of transient elastography, Fibrotest, APRI, and liver biopsy for the assessment of fibrosis in chronic hepatitis C. Gastroenterology 2005, 128:343-350.

13. Naveau S, Poynard T, Benattar C, Bedossa P, Chaput JC: Alpha-2macroglobulin and hepatic fibrosis. Diagnostic interest. Dig Dis Sci 1994, 39:2426-2432

14. Patel K, Gordon SC, Jacobson I, Hézode C, Oh E, Smith KM, Pawlotsky JM, McHutchison JG: Evaluation of a panel of non-invasive serum markers to differentiate mild from moderate-to-advanced liver fibrosis in chronic hepatitis C patients. J Hepatol 2004, 41:935-942.

15. Calès $P$, Oberti F, Michalak S, Hubert-Fouchard I, Rousselet MC, Konaté A, Gallois Y, Ternisien C, Chevailler A, Lunel F: A novel panel of blood markers to assess the degree of liver fibrosis. Hepatology 2005, 42:1373-1381.

16. Adams LA, Bulsara M, Rossi E, DeBoer B, Speers D, George J, Kench J, Farrell G, McCaughan GW, Jeffrey GP: Hepascore: an accurate validated predictor of liver fibrosis in chronic hepatitis $\mathrm{C}$ infection. Clin Chem 2005, 51:1867-1873.

17. Tiggelman AM, Boers W, Moorman AF, de Boer PA, Van der Loos CM, Rotmans JP, Chamuleau RA: Localization of alpha 2-macroglobulin protein and messenger RNA in rat liver fibrosis: evidence for the synthesis of alpha 2-macroglobulin within Schistosoma mansoni egg granulomas. Hepatology 1996, 23:1260-1267. 
18. Tiggelman AM, Linthorst C, Boers W, Brand HS, Chamuleau RA: Transforming growth factor-beta-induced collagen synthesis by human liver myofibroblasts is inhibited by alpha2-macroglobulin. $J$ Hepatol 1997, 26:1220-1228.

19. Meisse D, Renouf S, Husson A, Lavoinne A: Cell swelling increased the alpha2-macroglobulin gene expression in cultured rat hepatocytes. FEBS Lett 1998, 422:346-348.

20. Kawser CA, Iredale JP, Winwood PJ, Arthur MJ: Rat hepatic stellate cell expression of alpha2-macroglobulin is a feature of cellular activation: implications for matrix remodelling in hepatic fibrosis. Clin Sci (Lond) 1998, 95:179-186.

21. Gangadharan B, Antrobus R, Dwek RA, Zitzmann N: Novel serum biomarker candidates for liver fibrosis in hepatitis $\mathrm{C}$ patients. Clin Chem 2007, 53:1792-1799.

22. Rothermundt M, Arolt V, Peters M, Gutbrodt H, Fenker J, Kersting A, Kirchner $\mathrm{H}$ : Inflammatory markers in major depression and melancholia. J Affect Disord 2001, 63:93-102.

23. Tsiouris JA, Mehta PD, Patti PJ, Madrid RE, Raguthu S, Barshatzky MR, Cohen IL, Sersen E: Alpha2 macroglobulin elevation without an acute phase response in depressed adults with Down's syndrome: implications. J Intellect Disabil Res 2000, 44(Pt 6):644-653.

24. Daiger SP, Schanfield MS, Cavalli-Sforza LL: Group-specific component (Gc) proteins bind vitamin D and 25-hydroxyvitamin D. Proc Natl Acad Sci USA 1975, 72:2076-2080.

25. Bouillon R, Auwerx J, Dekeyser L, Fevery J, Lissens W, De Moor P: Serum vitamin $D$ metabolites and their binding protein in patients with liver cirrhosis. J Clin Endocrinol Metab 1984, 59:86-89.

26. Lee WM, Galbraith RM: The extracellular actin-scavenger system and actin toxicity. N Engl J Med 1992, 326:1335-1341

27. Schiodt FV, Bangert K, Shakil AO, McCashland T, Murray N, Hay JE, Lee WM: Predictive value of actin-free Gc-globulin in acute liver failure. Liver Transp/ 2007, 13:1324-1329.

28. Antoniades CG, Berry PA, Bruce M, Cross TJ, Portal AJ, Hussain MJ, Bernal W, Wendon JA, Vergani D: Actin-free Gc globulin: a rapidly assessed biomarker of organ dysfunction in acute liver failure and cirrhosis. Liver Transp/ 2007, 13:1254-1261.

29. Myers RP, Ratziu V, Imbert-Bismut F, Charlotte F, Poynard T: Biochemical markers of liver fibrosis: a comparison with historical features in patients with chronic hepatitis C. Am J Gastroenterol 2002 97:2419-2425.

30. Poynard T, Imbert-Bismut F, Ratziu V, Chevret S, Jardel C, Moussalli J, Messous D, Degos F: GERMED cyt04 group. Biochemical markers of liver fibrosis in patients infected by hepatitis $C$ virus: Iongitudinal validation in a randomized trial. J Viral Hepat 2002, 9:128-133.

31. Tonge R, Shaw J, Middleton B, Rowlinson R, Rayner S, Young J, Pognan F, Hawkins E, Currie I, Davison M: Validation and development of fluorescence two-dimensional differential gel electrophoresis proteomics technology. Proteomics 2001, 1:377-396.

32. Orenes-Pinero E, Corton M, Gonzalez-Peramato P, Algaba F, Casal I, Serrano A, Sanchez-Carbayo M: Searching urinary tumor markers for bladder cancer using a two-dimensional differential gel electrophoresis (2D-DIGE) approach. J Proteome Res 2007, 6:4440-4448.

33. Van den Bergh G, Clerens S, Cnops L, Vandesande F, Arckens L: Fluorescent two-dimensional difference gel electrophoresis and mass spectrometry identify age-related protein expression differences for the primary visual cortex of kitten and adult cat. J Neurochem 2003, 85:193-205

34. Zhou G, Li H, DeCamp D, Chen S, Shu H, Gong Y, Flaig M, Gillespie JW, Hu N, Taylor PR, Emmert-Buck MR, Liotta LA, Petricoin EF, Zhao Y: 2D differential in-gel electrophoresis for the identification of esophageal scans cell cancer-specific protein markers. Mol Cell Proteomics 2002, 1:117-124.

35. Gharbi S, Gaffney P, Yang A, Zvelebil MJ, Cramer R, Waterfield MD, Timms JF: Evaluation of two-dimensional differential gel electrophoresis for proteomic expression analysis of a model breast cancer cell system. Mol Cell Proteomics 2002, 1:91-98.

36. Van den Bergh G, Clerens S, Vandesande F, Arckens L: Reversed-phase high-performance liquid chromatography prefractionation prior to two-dimensional difference gel electrophoresis and mass spectrometry identifies new differentially expressed proteins between striate cortex of kitten and adult cat. Electrophoresis 2003, 24:1471-1481.

37. Bataller R, Brenner DA: Liver fibrosis. J Clin Invest 2005, 115:209-218.
38. Johansen JS, Christoffersen P, Moller S, Price PA, Henriksen JH, Garbarsch C, Bendtsen F: Serum YKL-40 is increased in patients with hepatic fibrosis. J Hepatol 2000, 32:911-920.

doi: $10.1186 / 1423-0127-17-58$

Cite this article as: $\mathrm{Ho}$ et al., Novel biomarkers predict liver fibrosis in hepatitis $C$ patients: alpha 2 macroglobulin, vitamin D binding protein and apolipoprotein Al Journal of Biomedical Science 2010, 17:58

\section{Submit your next manuscript to BioMed Central and take full advantage of:}

- Convenient online submission

- Thorough peer review

- No space constraints or color figure charges

- Immediate publication on acceptance

- Inclusion in PubMed, CAS, Scopus and Google Scholar

- Research which is freely available for redistribution

Submit your manuscript at www.biomedcentral.com/submit
C) Biomed Central 